\title{
The Information Content of Sudden Removal of Corporate Chief Executives-Evidence from the Nigerian Banking Sector
}

\author{
Alex E. Osuala ${ }^{1}$, Philip O. Nto ${ }^{1} \&$ Samuel F. Akpan ${ }^{1}$ \\ ${ }^{1}$ Department of Banking and Finance, Michael Okpara, University of Agriculture, Umudike, Nigeria \\ Correspondence: Dr. Alex E. Osuala, Department of Banking and Finance, Michael Okpara University of \\ Agriculture, Umudike, Nigeria. Tel: 234-803-060-6878. E-mail: osuala.alex@mouau.edu.ng
}

Received: March 12, 2013

Accepted: June 4, $2013 \quad$ Online Published: June 26, 2013

doi:10.5539/ijef.v5n8p101

URL: http://dx.doi.org/10.5539/ijef.v5n8p101

\begin{abstract}
This study investigates the information content of sudden removal of banks' chief executive officers (CEOs) in the Nigerian emerging stock market context. Mainly secondly data collected from the Nigerian Stock Exchange daily official list and those extracted from financial standard Newspapers were used. Event study methodology was employed in determining the impact of the unexpected removal of the bank executives on the prices of their banks' stocks. The data was analyzed using regression analysis with the E-views 7.0 econometric package. The findings show that the ouster of the bank CEOs did not significantly impact on the stock prices of Afribank Plc, FinBank Plc, Oceanic Bank Plc, Intercontinental Bank Plc and Union Bank of Nigeria Plc. The non-insignificance but positive information effect of the ouster could be as a result of the prompt intervention by the CBN via the injection of N420 billion intervention fund into the banking sector on one hand, and on the other hand, perhaps because trading on the stocks of the affected banks stopped with the ouster of the CEOs for close to a period of two weeks. The positivity of the average abnormal returns tend to suggest that investors in the Nigerian stock market saw the development as "a good riddance of old rubbish". The study therefore recommends that the $\mathrm{CBN}$ should maintain a closer surveillance on the banking sector so as to be able to detect in good time any rot in the system before it blossoms into a "financial epidemic".
\end{abstract}

Keywords: information content, ouster, event study methodology, stock market

\section{Introduction}

The global economic meltdown that trickled into Nigeria during the third quarter of 2008 gained root in 2009 with serious effects on the formal and informal sectors of the Nigerian economy. The effect in the capital market defiled all measures put in place by regulators to boost the market during the year.

There were significant occurrences in the banking sector in the year 2009. However, the most striking occurrence in the sector during the year was the drastic reformation of the banking sector carried out by the Governor of the Central bank of Nigeria (CBN) Mallam Sanusi Lamido Sanusi which resulted in the sudden removal of the Managing Directors of eight Nigerian commercial banks. In the first exercise, five bank chief executives were sacked on Friday, the 14th of August 2009, namely: Mrs. Cecilia Ibru (Oceanic Bank International Plc), Mr. Sabastine Adigwe (Afribank Plc), Mr. Erastus Akingbola (Intercontinental Bank Plc), Mr. Bartholomew Ebong (Union Bank Plc) and Mr. Emeka Nwosu (FinBahk Plc). CBN replaced the Chief Executive officers (CEOs) and their management teams with interim management committees to supervise the affected banks pending the successful transfer of ownership to new investors.

It is pertinent to note that Sanusi's action resulted from reports of audits carried out on the banks by the apex bank. According to the CBN, the affected banks were in grave financial situation because of unsecured loans that were not repaid. A greater percentage of the loans turned out to be margin loans given to even people who did not apply for them. While addressing a press conference in Lagos on Friday, 14lh August 2009, to announce the apex's bank decision, Sanusi said that CBN had to respond swiftly to tackle the glaring weakness in risk management and corporate governance in some of the banks and to stem possible systemic crisis and restore public confidence in the Nigerian banking sector. He further hinged the decision to remove the affected Managing Directors to excessively high level of non-performing loans in their loans portfolios, which he attributed to poor corporate governance practices, lax credit administration process and the banks' poor credit risk management. 
The major criteria used for determining the status of the banks include the number of times the banks approached the Central Bank of Nigeria Expanded Discount Window (EDW) and the inter-bank market to shore up liquidity, the percentage of non-performing loans to total loan portfolio and relative share of non-performing loans to the entire industry.

With respect to the affected banks, the Central Bank of Nigeria gave the following statistics to back up its actions:

Table 1. Statistics from the Central Bank of Nigeria

\begin{tabular}{ll}
\hline Items & Amount \\
\hline I. Total loan portfolio & N2.8 trillion \\
2. Total margin Loans & N456 billion \\
3. Exposure to Oil and Gas & N487 billion \\
4. Total non-performing Loan & N1.143 trillion (representing 40.18\%) \\
5. Outstanding balance at EDW & N 127.85 billion (representing $89.81 \%)$ \\
6. Net guaranteed Interbank takings & N253.30 billion \\
7. Liquidity Ratio & N17.65\% - 24\% i.e., (below 25\% minimum) \\
8. Capital Adequacy Ratio & Below $10 \%$ minimum (one had $1.01 \%)$ \\
9. Market share - Total Assets & $31.47 \%$ \\
10. Market Share - Deposits & $29.99 \%$ \\
11. Market Share - Loans & $39.93 \%$ \\
12. Minimum Capital Required & N204.94 billion \\
\hline
\end{tabular}

Source: Akpan (2012)

However, as a bailout measure, the CBN injected N420 billion into the five banks.

According to the Central Bank of Nigeria, in exercise of its powers under section 33 and 35 of the Bank and other Financial Institutions Act 1991, as amended; the apex bank sacked the former CEOs. However, the CBN's action was greeted with mixed feelings and reactions. While most financial analysts said it was a right move to strengthen the banking industry, critics argued that the CBN was hasty to take such a sensitive action which could boomerang on the economy and therefore condemned it as unjust. However you may want to look at it, this was a significant development in the Nigerian banking sector.

Theoretically, Board changes, forced or voluntary resignation, are expected to convey information to the securities market, depending on how the market views such changes; that is, whether it is considered as being beneficial to the interest of the shareholders or not. Thus, the sudden or unexpected removal of a CEO conveys a signal to the stock market. In response to such changes, the stock market reacts. The reaction is measured through the abnormal returns experienced at the announcement of such sacks, which could be positive if the change is seen as a good development, or negative if otherwise.

This study appears unique in its focus in that there is no study known to the authors to date that has tried to investigate the information effect of the sudden removal of the five bank CEOs in Nigeria.

\section{Theoretical Framework}

Numerous studies have documented that the announcement of an unexpected change in corporate governance is associated with a change in a firm's stock price. Specifically, it is said that the stock market reacts positively to unexpected changes that are deemed to enhance shareholders' wealth, and negatively to such changes that are believed to have negative consequences on the wealth of shareholders. Understanding the relationship between unexpected news in the stock market and stock price changes consequent upon release of such news has been a key concern in stock market research.

Unexpected changes in corporate top managements are often associated with reactions in stock price. To measure the information effect of unexpected removal of the CEO of a big corporate entity, a number of studies have used the abnormal returns method. The abnormal return is the difference between the realized returns, Rit and the expected returns, E(Rt) given the level of systematic risk. This approach to event study was used by Ryan et al 
(2000), Travlos et al (2001), Amihud and Li (2002), De Medeiros and Matsumoto (2004), among others.

The abnormal return can be calculated over a period of time before and after the ouster announcement, using the capital asset pricing model (CAPM), or the market model like Aharony and Swary (1980) did in their study. The market model tries to relate the individual security's return to the market return or its proxy linearly.

\section{Research Methodology}

The research method adopted for any research work is of utmost importance. This is because the accuracy, reliability and acceptability or otherwise of a study depends to a large extent on the methodology adopted. Methodology adopted provides the background against which a reader evaluates the findings and conclusions drawn from the study.

\subsection{Types and Sources of Data}

The study utilized mainly secondary data collected from the Nigerian Stock Exchange (NSE) over a period of 12 days which covers both the estimation and event window (Note that after the event day - 14th August 2009, the stocks of these banks disappeared from the market until 1st, September 2009). So, the data stream for the study consisted of the Nigeria Stock Exchange Daily Official list on the five affected banks. Other relevant pieces of information were extracted from the Nigeria Stock Exchange Fact Book and some national dailies.

\subsection{Analytical Framework}

The analytical method employed in this study is the standard event study methodology. As observed by Wirjanto (2005), the objective of an event study is to measure the effect of an economic event on the value of firms. Using financial market data, an event study measures the impact of a specific event on the value of a firm. The basis and usefulness of such a study stems from the belief that, given rationality in the market place, the effects of an event will be reflected instantaneously in security prices (Osuala, 2005). So, a measure of the event's economic impact can be constructed using security prices observed over a relatively short time period.

The basic steps in event study entail:

Clear definition of the event of interest and the period over which the security prices of the firms involved in the event would be examined.

Definition of the selection criteria

Definition of the event window and the estimation window

Calculation of the abnormal, actual and expected returns

Aggregation of the abnormal returns to obtain the cumulative abnormal returns

Designing a testing framework for the cumulative abnormal returns.

\subsection{Calculating the Abnormal Returns}

According to Osuala (2005) the abnormal return is the actual return of the security minus its expected rate of return over the event window. Expected return on the other hand is the return that would be expected if the event of interest did not take place. This implies that for each firm $i$ and event date $t$, we have:

$$
e_{i t}=R_{i t}-E\left(R_{i t} / X_{t}\right)
$$

eit $=$ the abnormal returns for the period, $\mathrm{t}$

Rit $=$ actual return

$\mathrm{E}(\mathrm{Rit})=$ normal $($ or Expected) returns for the period $\mathrm{t}$

$\mathrm{Xt}=$ the conditional information for normal performance model.

For this research work the abnormal returns are calculated using the single factor market model which assumes that the return on each security is linearly related to the market portfolio return or its market proxy and it is given as:

$$
R_{i t}=\alpha_{i}+\beta_{i} R_{m t}+e_{i t}
$$

Rit is realized rate of the ith security during period, $t$.

$\mathrm{Rmt}$ is rate of return on the equally weighted market index at period, t. 
eit is a random variable that is expected to have a value of zero.

$\alpha_{i}$ and $\beta_{i}$ are the intercept and slope parameters for the firm i, respectively.

This implies that the abnormal return (AR) for the ith common stock on day t, is given by

$$
A R_{i t}=R_{i t}-\left[\hat{\alpha}_{i}+\hat{\beta}_{i} R_{m t}\right]
$$

where $\left[\hat{\alpha}_{i}+\hat{\beta}_{\mathrm{i}} R_{\mathrm{mt}}\right]$, is the expected rate of return, $\mathrm{E}(\mathrm{R})$;

the coefficients $\hat{\alpha}$ and $\hat{\beta}$ are ordinary least squares estimates of $\alpha$ and $\beta$ estimated from a regression of daily security returns on daily market returns from $t=-7$ to $t=-3$ (where $t=0$ is the event date, and $t=-7$ to $t=-3$ is the estimation window).

The individual securities abnormal returns, ARit is aggregated and averaged across all the observations to obtain the average of the average abnormal returns using the formula below

$$
A A R_{t}=\frac{\sum_{i=1}^{N} A R_{i t}}{N}
$$

Where $\mathrm{N}=$ is the number of events in the sample or in other words number of companies in the sample, AARt $=$ average abnormal return.

Next, the average abnormal returns are aggregated over the event window to give the cumulative average abnormal returns (CAAR), for any interval in the event window.

$$
C A A R_{t}=\sum_{t-k}^{t} A A R_{t}
$$

where $C A A R_{t}$ is the sample cumulative abnormal returns from $\mathrm{t}-\mathrm{k}$ day to $\mathrm{t}$ day of the event window (i.e., -2 to $+4)$.

CAARt and AARt are then tested for their statistical significance using the standard event study t-test formula given as:

$$
t_{\left(A A R_{t}\right)}=\frac{A A R_{t}^{E P}}{\sigma\left(A R_{i t}\right)}
$$

for the average abnormal return,and

$$
t_{(C A A R)}=\frac{C A A R}{\left(\sigma_{N, \mathrm{Pr} e} \sqrt{N_{t}}\right)}
$$

for the cumulative average abnormal return;

where $\sigma\left(A R_{i t}\right)=$ the standard deviation of the average abnormal return calculated from the pre-event window, $A A R_{t}{ }^{E P}=$ average abnormal return in the event period, EP.

$\sigma_{N, \text { Pre }}=$ aggregate of pre-event standard deviation of abnormal returns across all securities.

$\mathrm{Nt}=$ the absolute value of the event day, t, plus 1 (e.g. for event day -2 , the absolute value is 2 , and $\mathrm{Nt}=3$ );

and

$$
\sigma\left(A R_{i t}\right)=\sqrt{\frac{\sum_{-7}^{-4}\left(A R_{i t}-A A R_{p r e}\right)^{2}}{n-1}}
$$

where $A A R_{\text {pre }}=$ average of abnormal returns of each security estimated from the pre-event period; $\mathrm{n}=$ number of days in the pre-event period.

If CAARt and AARt are significant, it can then be said that the information caused by the event has had an impact on the share prices of the five affected Banks. 


\section{Data Presentation, Analysis of Data and Discussion of the Research Findings}

\subsection{Data Presentation and Analysis}

Following the sample selection criteria as discussed earlier in section three, we present here data on the estimated abnormal returns for the five banks.

Table 2. Calculated abnormal return for the event period for the five banks

\begin{tabular}{cccccc}
\hline $\begin{array}{c}\text { AfriBank } \\
(\mathrm{AR})\end{array}$ & First-In Land (AR) & $\begin{array}{c}\text { Intercontinental } \\
\text { (Bank (AR) }\end{array}$ & Oceanic (AR) & UBN (AR) & Date \\
\hline 0.033 & -0.001 & 0.031 & 0.017 & 0.013 & $12 / 8 / 09$ \\
0.036 & 0.008 & 0.010 & 0.003 & 0.083 & $13 / 8 / 09$ \\
0.061 & 0.008 & 0.014 & 0.037 & 0.089 & $14 / 8 / 09$ \\
-0.010 & 0.019 & 0.010 & 0.057 & 0.085 & $1 / 9 / 09$ \\
0.071 & 0.019 & 0.007 & 0.067 & 0.125 & $2 / 9 / 09$ \\
0.091 & 0.003 & 0.027 & 0.077 & 0.154 & $3 / 9 / 09$ \\
-0.010 & 0.019 & 0.037 & 0.087 & 0.175 & $4 / 9 / 09$ \\
\hline
\end{tabular}

From Table 2 it is observed that the abnormal return of AfriBank Nig Plc within the event window varies within the range of -0.010 to 0.091; First Inland Bank Plc from - 0.001 to 0.019; Intercontinental Bank Plc from 0.010 to 0.037 ; Oceanic Bank Nig Plc from 0.003 to 0.087 while UBA abnormal return within the period varies between 0.013 to 0.175 .

The averaged abnormal returns are as presented Table 3 together with the cumulative of the averaged abnormal return.

Table 3. Averaged abnormal return and cumulative abnormal return for the event period

\begin{tabular}{ccc}
\hline Date & $A A R_{t}^{E P}=\frac{\sum_{i=1}^{N} A R_{i t}{ }^{E P}}{N}$ & $C A A R_{t}=\sum_{t-k}^{t} A A R_{t}$ \\
& 0.0186 & 0.0186 \\
$12 / 8$ & 0.0280 & 0.0466 \\
$13 / 8$ & 0.0362 & 0.0828 \\
$1 / 9$ & 0.0322 & 0.1150 \\
$2 / 9$ & 0.0578 & 0.1728 \\
$3 / 9$ & 0.0706 & 0.2434 \\
$4 / 9$ & 0.0616 & 0.3050 \\
\hline
\end{tabular}

The estimation period abnormal return is presented in the table below.

Table 4. Abnormal return for the estimation period

\begin{tabular}{cccccc}
\hline Date & Afribnak (AR) & First Inland (AR) & Intercontinental (AR) & Oceanic (AR) & UBN (AR) \\
\hline $5 / 8 / 09$ & 0.047 & 0.003 & -0.005 & 0.017 & -0.046 \\
$6 / 8 / 09$ & 0.001 & 0.002 & 0.084 & 0.567 & 0.029 \\
$7 / 8 / 09$ & 0.031 & -0.001 & 0.152 & 0.023 & -0.003 \\
$10 / 8 / 09$ & 0.036 & 0.000 & 0.017 & -0.007 & -0.017 \\
$11 / 8 / 09$ & -0.012 & -0.001 & 0.009 & -0.019 & 0.025 \\
\hline
\end{tabular}

The abnormal returns over all securities are now averaged for all the estimation period; the result is as presented in the Table 5 below. 
Table 5. Average abnormal returns for the estimation period

\begin{tabular}{cc}
\hline Date & $A A R_{t}=\frac{\sum_{i=1}^{N} A R_{i t}}{N}$ \\
& -0.0156 \\
$6 / 8 / 09$ & 0.1206 \\
$7 / 8 / 09$ & 0.0404 \\
$10 / 8 / 09$ & 0.0058 \\
$11 / 8 / 09$ & -0.0032 \\
& $=0.148$ \\
\hline
\end{tabular}

$\mathrm{EsP}=$ estimation period

Then, the average abnormal return across all firms for the whole estimation period is the average of the average abnormal return in the estimation period.

Therefore

$$
\overline{A A R}_{t}{ }^{E s}=\frac{0.148}{5}=0.0296
$$

Table 6. Calculation of standard deviation

\begin{tabular}{cccc}
\hline$A A R_{t}$ & $\overline{A A R_{t}}{ }^{s P}$ & $\left(A A R_{t}-\overline{A A R}\right)^{2}$ & $\left(A A R_{t}-\overline{A A R}\right)^{2}$ \\
\hline-0.0156 & 0.0296 & -0.0452 & 0.002 \\
0.1206 & 0.0296 & 0.091 & 0.0083 \\
0.0404 & 0.0296 & 0.0108 & 0.0001 \\
0.0056 & 0.0296 & -0.0238 & 0.0238 \\
-0.0032 & 0.0296 & -0.0328 & 0.0010 \\
\hline
\end{tabular}

$$
\begin{gathered}
\left(A A R_{t}-\overline{A A R}\right)^{2}=0.0343 \\
\sigma\left(A R_{t}\right)=\sqrt{\frac{0.0343}{5-1}}=0.0927
\end{gathered}
$$

Lastly, we test each average abnormal return in the event period for significance. This is simply done by dividing each average abnormal return in the event period by the standard deviation estimate calculated; using the formula

$t=\frac{\overline{A R}_{t}^{E P}}{\sigma\left(A R_{i t}\right)}$. The result of this is presented in Table 7. 
Table 7. Calculation of t-test

\begin{tabular}{lccc}
\hline$A R_{t}^{E P}$ & $\sigma\left(A R_{i t}\right)$ & Calculated $t$ & Tabular $t$ - Value \\
\hline 0.0186 & 0.0927 & 0.2006 & $(2.36)$ \\
0.0280 & 0.0927 & 0.3020 & $(2.36)$ \\
0.0362 & 0.0927 & 0.3905 & $(2.36)$ \\
0.0322 & 0.0927 & 0.3474 & $(2.36)$ \\
0.0578 & 0.0927 & 0.6235 & $(2.36)$ \\
0.0706 & 0.0927 & 0.7616 & $(2.36)$ \\
0.0616 & 0.0927 & 0.6645 & $(2.36)$ \\
\hline
\end{tabular}

\subsection{Discussion of the Research Findings}

From the t-test as shown in Table 7, the $t$ values ranging from 0.2006 to 0.7616 are not statistically significant at $5 \%$ level. The abnormal returns are therefore not significantly different from zero. It can therefore be concluded that the sudden removal of the bank chief executive directors did not significantly impact on the share prices of Afribank Nigeria plc, FinBank Plc, Oceanic Bank Plc, Intercontinental Bank Plc and Union Bank Nigeria Plc.

The non-insignificance of the information effect of the ouster could be as a result of instant intervention by the CBN via the injection of N420 billion intervention fund into the banking sector on one hand, and on the other hand, perhaps because trading on the stocks of the affected banks stopped with the ouster of the chief bank executives for close to a period of two weeks.

It is important to note however that since there was positive abnormal average returns, which though were insignificant, it implies that investors in the Nigerian stock market saw the development as "a good riddance of old rubbish".

\section{Conclusions \& Recommendations}

\subsection{Conclusion}

In this study, we examined the information content of the sudden removal of the chief executive directors of five Nigerian banks. Following the research findings, we conclude that:

-The information contents of the sudden removal had no significant impact on share market price.

-The CBN lead by its governor Lamido Sanusi cushioned the would-have-been effect of the ouster through the injection of N420 billion which was later increase to N620 billion into the bank sector.

-Again, since there were positive abnormal average returns, which though were insignificant, it implies that investors in the Nigerian stock market saw the development as a good riddance.

\subsection{Recommendations}

Following the findings of this research which reveals that the sudden removal of chief executive directors of the five banks had non-significant but positive impact on the market share prices of the affected stocks, which as observed earlier is sequel to the prompt intervention of the CBN through the injection of N420 billion into the banking industry, the study recommends that the CBN should maintain a closer surveillance on the banking sector so as to be able to detect in good time any rot in the system before it blossoms into a "financial epidemic".

Secondly, considering the importance of adequate and affordable data stream in empirical research works, it is highly recommended that the federal Government of Nigeria should as a matter of urgency set up a body that would (or through the agency of already established organizations) ensure that a good data bank is in place, similar to what obtains in developed markets of the world, to encourage research efforts. What obtains presently at the Nigeria stock Exchange, which amounts to passing through the eyes of the needle to collect necessary data is all but cheering.

\section{References}

Aharony, J., \& Swary, I. (1980). Quarterly dividend and earnings announcements and stockholder's return: An empirical analysis. Journal of Finance, 35, 1-12. http://dx.doi.org/10.1111/j.1540-6261.1980.tb03466.x

Akpan, S. F. (2012). The information content of sudden sack of corporate chief executives. An Unpublished BSc Project Submitted to the Department of Banking \& Finance, Michael Okpara University of Agriculture, umudike, Nigeria. 
Amihud, Y., \& Li, K. (2002). The declining information content of dividend announcements and the effect of institutional holdings. Working Paper, New York University.

Campbell, J., Lo, A. W., \& Mackinlay, A. C. (1985). The Econometrics of Markets. Princeton: Princeton University Press.

De Medeiros, O. R., \& Matsumoto, A. S. (2004). Market reaction and volatility in the Brazilian stock market. Brazil.

Osuala, A. E. (2005). The information content of dividend policy changes in an emerging stock market-the nigerian experience. An unpublished PhD Dissertation, Abia State University, Uturu, Nigeria.

Ryan, P. A., Besley, S., \& Lee, H. W. (2000). An empirical analysis of reactions to dividend policy changes for NASDAQ firms. Journal of Financial and Strategic Decisions, 13(1).

Travlos, N., Lenos, T., \& Nikos, V. (2001). Shareholder wealth effects of dividend policy changes in an emerging stock market: The case of cyprus. Multinational Finance Journal, 5(2), 27-112.

Warner, J. B., Watts, R. L. \& Wruck, K. H. (1988). Stock price and top management changes. Journal of Financial Economics, 20, 461-92. http://dx.doi.org/10.1016/0304-405X(88)90054-2

Wirjanto, T. S. (2005). Lecture on event-study analysis, a Monograph, Zhejiang University.

\section{Copyrights}

Copyright for this article is retained by the author(s), with first publication rights granted to the journal.

This is an open-access article distributed under the terms and conditions of the Creative Commons Attribution license (http://creativecommons.org/licenses/by/3.0/). 